\title{
High-frequency contrastive grammar features of the Uralic languages
}

\author{
Vladimir N. Polyakov - Elena A. Makarova - Ekaterina S. Paramoshko
}

DOI: 10.18355/XL.2018.11.01.15

\begin{abstract}
The present article is dedicated to the detection of the ancestral homeland of the Uralic languages and their relevant features. Linguistic geophylogeny used within the framework of the research allowed proving the "Eastern" hypothesis on their ancestral homeland. The method of contrastive queries based on the LangFam program and the database "Languages of the World" defined a set of relevant features of the Uralic languages. Their dominating word order "subject-verb-object" was proved to be nongenealogic. The research found a high correlation between the word order and the number of cases in the Uralic languages. The possible ways of the Uralic people's migration and the linguistic contacts appearing during their settlement were studied.

Key words: Uralic languages, contrastive queries, word order, linguistic geophylogeny, "Languages of the World" database, LangFam
\end{abstract}

\section{Introduction}

Detection of relevant features for a language family is a classic linguistic task (Danilova et al., 2016; Silnitsky, 2006; Tomlin, 1986). After the appearance of such linguistic resources as the database "Languages of the World" of the Institute of Linguistics of the Russian Academy of Sciences (IL RAS) (2013), which contains a big number of grammar features, researchers are given a free hand to use great arrays of data in search for relevant features. The present paper is aimed at studying the Uralic languages from the point of view of their relevant features.

The Uralic languages are a big family of languages spoken in Asia and Europe with over 25 million speakers. Some languages from the family have the status of official languages in Europe (such as Hungarian, Estonian, and Finnish). There are many works dedicated to the Uralic family or separate languages, but there are questions on the evolution of the Uralic languages that remain unanswered. For example, recently the dominant word order in different world languages has been studied very actively (Comrie, 1989; Dryer, 1992; Gell-Mann, Ruhlen, 2011; Rijkhoff, 2004). The following works also studied the question of the word order in the world languages (Greenberg, 1963; Haugan, 2001; Hoffman, 1996; Song, 2012; Tomlin, 1986). Numerous linguistic studies are dedicated to the appearance and typology of the Uralic languages (Collinder, 1965; Hajdu, 1985; Janhunen, 2009; Marcantonio, 2002; Napolskikh, 1991, 1997). However, there has still been no comprehensive work dedicated to the reasons and the time when the word order changed in the Uralic languages so far.

The present work regards the facts that the dominant word order in some Uralic languages changed:

in some languages from "subject-object-verb" (SOV) to "subject-verbobject" (SVO) under the influence of the neighboring Indo-European languages (Germanic and Slavic) before the XVI AD (Ehala, 2006);

in some languages from SOV to free word order.

Moreover, the SOV $\rightarrow \mathrm{SVO}$ change was accompanied by an enrichment of the case system, which is confirmed by statistical data.

The present research is based on the combination of typological, geographical, genealogical and geophylogenetic data on the Uralic language family from the database "Languages of the World" of IL RAS, as well as from the World Atlas of

XLinguae, Volume 11 Issue 1, January 2018, ISSN 1337-8384, eISSN 2453-711X 
Language Structures (WALS) and the Automated Similarity Judgment Program (ASJP). A detailed description of the "Languages of the World" IL RAS database (Spring 2013), LangFam program and the method of contrastive queries used during this research is given in (Danilova et al., 2016). For the first time, the location of the ancestral homeland of the Uralic languages is defined using the method of linguistic geophylogeny.

Section 2 of the paper presents an overview of the works on the Uralic languages and existing hypotheses of their areal contacts, ancestral homeland and ways of migration. Further, in Section 3, the authors suggest a description of the object of the present study and the main goals of the research. Section 4 contains information on the methods and resources used during the research. Sections 5 and 6 provide an analysis of the results and their relevance for the modern scholarship. In Section 7 we give a summary of the research and its results, discuss the limitations of the work and outline the direction of further studies.

\section{The Ancestral Homeland and Ways of Migration - Overview}

\subsection{Hypotheses on the ancestral homeland of Uralic languages}

Detection of the ancestral homeland of a language family is one of the most important issues of historical linguistics. The present work regards the existing hypotheses on the geographic localization of the ancestral homeland of the Uralic languages and further suggests the ways of specifying it.

The regions of distribution of the modern Uralic languages do not form a continuous space. The languages of the family in question are located as separate districts between $56^{\circ}$ and $70^{\circ} \mathrm{N}$ from Scandinavia to the Taymyr Peninsula. Besides, the area of distribution of Hungarian, which has the biggest number of speakers in the family, is located much more southwest of this region, in the territory surrounded by the Carpathian Mountains (see Figure 1).

The map shows the distribution of the Uralic languages across the continent. Markers in the map denote the center of the distribution area of the languages in question. The geographic coordinates of the area centers are taken from WALS (Udmurt, Yazva, Saami (Kildin), Saami (Central-South), Nenets (Tundra) and Mansi) and the "Languages of the World" IL RAS database (all other languages).

Despite rather long studies in this sphere, a unique and widely accepted hypothesis on the localization of the Uralic ancestral homeland still does not exist. First of all, all hypotheses can be divided into so-called "Eastern" and "Western" ones. According to the former, the origins of the Uralic languages are located in Asia, Western and Southern Siberia (Castrén, 1849; Wiedemann, 1838); according to the latter, the ancestral homeland is located in Europe, from the Baltic Sea to the Uralic Mountains (Hajdu, 1985). Noteworthy, the second point of view, which was dominating in science for a long time, does not solve the problem of the genesis of the Samoyedic people.

The Eastern hypothesis on the origin of the Uralic languages is described by V. Napolskikh (1997). Based on the data of linguistics paleontology, Napolskikh defines the Proto-Uralic ecologic area as a territory bordered by the Uralic Mountains in the West, by the Polar circle in the North, by the region on the lower stream of the Angara River and the Podkamennaya Tunguska River and by the middle stream of the Yenisei River in the East, by the southern border of Western Siberian Taiga from the northern Piedmont of the Sayan Mountains and the Altai Mountains to the lower stream of the Tobol River and the Middle Uralic Mountains. This hypothesis does not contradict the toponymical data. The data of the external genealogic and real connections of the Uralic proto-language (Häkkinen, 2012) also bring to the conclusion on the Northern Asian and Siberian directions of this link. 
Nevertheless, in general, an ecologic area defined by the method of linguistic paleontology and an ancestral homeland is not the same. The borders of the latter should also be defined based on the archaeological and anthropological data. Considering this, V. Napolskikh concludes that the Proto-Uralic ecological area coincides with the regions where Proto-Uralic speakers lived before the disintegration of the community. The western border lies further to the west of the border of the Uralic ecological area, near the interfluve of the Vyatka River and the Vetluga River, i.e., in the area of the archaeological border between the Uralic and West Siberian and Volga-Oksk neolith (Napolskikh, 1991).

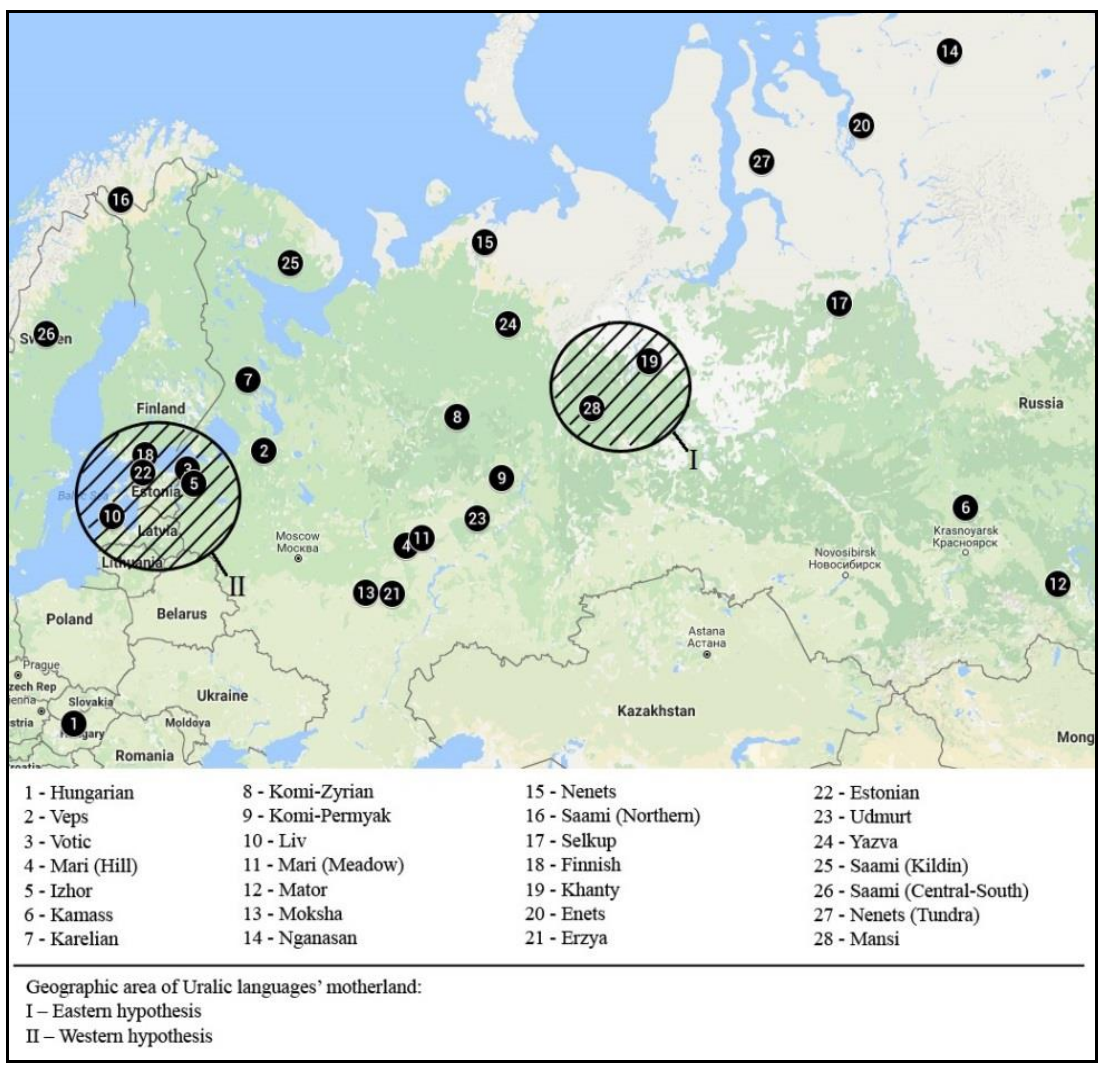

Figure 1: Geographic area of Uralic languages (All maps referred to in the paper are created using Google Maps)

\subsection{Ways of migration and areal contacts}

Let us look at the possible ways of migration of the Uralic people and language contacts arising along with their movement. It is important to remember that ethnogenesis is a very complicated process, which can cause merge of peoples, blend or even change of languages. That is why the problem of external contacts of the Uralic languages is also debatable and remains unsolved so far. For example, the reasons for the likeness of the Uralic and Yukaghir languages are unclear: some scholars classify the Yukaghir languages with the Uralic family, others consider the reason to be the result of contacts. Some researchers find some common features 
between the Uralic languages and the Chukotko-Kamchatkan and Eskimo languages. However, if such contacts did take place, they should be very ancient, as these common features are characteristic of both the Samoyedic and Finno-Ugric languages, thus, the supposed contacts could not bring about the difference between the Uralic languages in the basic word order and means of expressing subject-object meanings.

The fact of old contacts between separate branches of the Altaic family and the Uralic languages and between branches of the Indo-European languages and the Uralic languages is universally recognized, but there is no general hypothesis about the time of the first contacts.

As for contacts between the Uralic and Altaic languages, the linguistic data (Hajdu, 1985) testifies to continuous connections between the Uralic languages of the Eastern area and the Tungus languages since the existence of the Uralic unity. Besides, Samoyedic and Ugric show traces of the Turkic influence. Moreover, while contacts with the Samoyedic language are believed to have taken place before its disintegration, the presence of Turkic borrowings in Proto-Ugric remains debatable. According to V. Napolskikh (1997), if this contact took place, it was not long and could occur not earlier than at the end of a common Ugric era (III c. BC).

Let us now proceed to the Uralic and Indo-European contacts. If the ancestral homeland is localized correctly, after the disintegration of the Samoyedic and FinnoUgric people the general migration direction of the latter is from the East to the West, probably, with some shift to the South. According to the data of linguistic paleontology, in the III c. BC the Proto-Finno-Ugric ecological area should be located in the Middle Ural, in the Middle and South Trans-Urals, in the south-western sector of West Siberia with the possible inclusion of regions to the west of the Ural Mountains - basins of the Kama River, the Upper Vychegda River and upper reaches of the Pechora River. Based on the analysis of anthropological data, N. Mokshin (2009) also claims that the Cisurals, West and South Siberia are the most probable territory of formation of the ancestors of the modern Finno-Ugric people. This point of view conforms to the modern level of development of other types of historical sources.

Studies (Abaev, 1972; Harmatta, 1977; Kalima, 1936) show that borrowings in the Finno-Ugric languages have Iranian and common Aryan, as well as Indo-Aryan words. V. Napolskikh agrees with the traditional point of view that the first contacts between the Uralic and Indo-European languages took place after the disintegration of the corresponding proto-languages, namely between the Finno-Ugric proto-language and Proto-Indo-Aryan dialects (till late III c. BC). This hypothesis does not contradict the archaeological data. E. Kuz'mina (2007), who suggests the Indo-Aryan ethnic belonging of the Andronovo population, sticks to the point of view on contacts between the Indo-Aryan and Finno-Ugric people at the border of the forest and steppe regions of Eurasia. According to V. Napolskikh, this contact was continuous until the early Middle Ages, and Hungarian continued contacting with the Iranian languages in the XI c., after the disintegration of the Ugric community.

Proto-Tocharians were another group of Indo-Europeans who contacted with the Uralic peoples at a rather old period (Napolskikh, 1991).

Later the western Finno-Ugric peoples kept on contacting with the Indo-European peoples, but now with their European groups. The most popular theory is that the order of their meetings was the following:

- the Proto-Baltic people and the Baltic Finns (probably, Baltic-Finnish Saami);

- the Germans and the Baltic Finns, the Germans and the Saami (since early I c. AD), later - the Slavic people and the Mordvins.

The anthropological data testify to the genetic closeness of the Samoyedic people, Ugric people of West Siberia and Yeniseian people (now represented only by the Ket). 


\section{Word Order and Case System as the Object of the Research}

\subsection{Basic word order change}

The reconstruction of the Proto-Uralic languages (Hajdu, 1985), (Honti, 2013) signifies that the mother-tongue had SOV as the dominant word order. Meanwhile, most modern Uralic languages are characterized by SVO, which means that this change took place in the evolution of the Uralic family. Let us look at certain languages and some reconstructions to understand when the change of the word order took place.

\subsubsection{The prevailing point of view concerning the change of word order $S O V \rightarrow S V O$}

The modern Permic languages have both word orders in question: SVO is dominant in Komi-Zyrian and Komi-Permyak, SOV - in Udmurt (Winkler, 2001). V. Ponaryadov (2001) conducted a comparative analysis of the order of the sentence constituents in the Permic languages and reconstructed the word order in the Permic proto-language. The author concluded that Permic had SOV word order, and all three languages (Komi-Zyrian, Komi-Permyak, and Udmurt) went through the SOV $\rightarrow$ SVO evolution, though the Udmurt system was much less modernized than those of the Komi languages. V. Ponaryadov explains this by the fact that Russian and the neighboring Turkic languages (Tatar and Chuvash) did not exert such influence on Udmurt. The author dates these changes back to XVI-XVII centuries, as the study of diachronic data shows the absence of any significant changes since XVIII c.

There are also some data on Estonian since XVI c. M. Ehala (2006) presents data from the corpus of the University of Tartu, which contains texts in literary Estonian of the XVI c. He analyzed 76 clauses from the viewpoint of the word order and position of the verb and found that the verb was located in the final position in $52.4 \%$ of all clauses. Nevertheless, this corpus does not contain a big number of texts. Moreover, some of them were written by non-native speakers, which could influence the reliability of the data.

Believing that the old word order (SOV) could be preserved in folk sayings and idioms, M. Ehala also analyzed Estonian folklore. He revealed cases when the verb occurred in the second position in the main clause. The SOV order is common for subordinate clauses.

The research by M. Ehala (2006) also refers to the results of another study (Remmel, 1963). The author of the latter work randomly chose 28 pages from a collection of folk fairy tales "Eesti rahvanaljandid" (Estonian fairy tales) and calculated the number of subordinate clauses with a verb in the final position. The result turned out to be 152 clauses out of 171. Similar calculations were made for "Valimik eestivanasõnu" [Collection of Estonian sayings]. The verb occurred in the final position in 322 of 381 clauses. Since modern Estonian has SVO as dominant word order, the data of the research in question can testify to the evolution SOV $\rightarrow \mathrm{SVO}$ at the period when these literary monuments were created.

Concerning modern Finnish, despite several studies claiming the absence of dominant word order (Braticco, 2016), most researchers agree that the SVO word order is also dominating. Nevertheless, E.Tsypanov (2008) has data that the runes of the national epos "Kalevala" (first published in 1835) still have SOV as the dominant order.

Nevertheless, we can also speak about "SOV $\rightarrow$ free word order" change, as there are at least two languages that do not have a dominating word order - Votic and Saami.

\subsection{Case system of the Uralic languages}

The modern Uralic languages differ from each other in the number of cases. Noteworthy, the data on their number for the same language often vary. It can be accustomed to by the criteria scholars use to differentiate between case forms and

XLinguae, Volume 11 Issue 1, January 2018, ISSN 1337-8384, eISSN 2453-711X 
adverbial formations or postpositional constructions.

Case systems of the Samoyedic languages have 7-8 elements (Hajdu, 1985), except Selkup, which has 13 cases (Kuznetsova et al., 2002). The Finno-Ugric languages show a significant variation in the number of cases. The richest case system belongs to Hungarian, which has up to 23 cases (Collinder, 1965). Komi-Zyrian and KomiPermyak are traditionally considered to have 16 cases each (Bubrih, 1949). Udmurt has 15 cases (Perevoshchikov et al., 1962), Finnish - 15 (Hakulinen, 1961), Estonian - 14 (Harms, 1962), Moksha - 13 (Serebrennikov, 1967), Erzya - 11 main cases and 6 additional (Evseviev, 1931), Veps - 22 (Zaitseva, 1981), Mari - 7 (Pengitov et al., 1961), Saami - 8-12 (Hajdu, 1985), Eastern dialects of Khanty have 10 cases, Southern dialects - 5, Northern - 3 (Hajdu, 1985), Mansi - 6 (Riese, 2001), Votic - 14 (Adler, 1966).

The existing reconstruction of the case system of Proto-Uralic (Hajdu, 1985) singles out 8 cases for it (suffix of each case is given in brackets):

- $\quad$ Nominative (ø);

- $\quad$ Genitive $(-n)$;

- $\quad$ Accusative $(-m)$;

- $\quad$ Locative (-na/-nä);

- $\quad$ Locative II (Characteristic of Proto-Finno-Ugric) (- $t$ );

- $\quad$ Ablative (-tal-tä);

- $\quad$ Lative-Dative I (-ń);

- $\quad$ Lative-Prolative II $(-k)$

As shown above, there are case systems in the Finno-Ugric languages that were considerably enriched compared to the proto-language, as well as case systems that now contain a small number of cases. The latter separate Nominative from local cases, but Genitive and Accusative relations are not marked by any special suffixes.

Besides case affixes, the Uralic languages have other means of expressing subjectobject and locative relations. For example, postpositional constructions are quite popular (they are very frequent in the Northern dialects of Khanty due to the small number of cases). Prepositions are used only in the Finnic languages. Moreover, the Samoyedic, Mordvinic and Ugric languages have subjective-objective verb conjugation. Some researchers believe that the opposition of subjective and objective conjugation developed in the groups mentioned above independently (Klemm, 19281942). Others claim that verbs in Proto-Uralic had two types of conjugation objective and objectless (Hajdu, 1985).

The selection of these two grammar characteristics - word order and case system will be explained in Section 4 of the present paper.

\section{Materials and Methods}

\section{1. "Languages of the World" database}

"Languages of the World" database is an electronic encyclopedic resource embracing the grammatical features of languages presented in the encyclopedia "Languages of the World." The current version of the database (Spring 2013) includes the description of 315 languages, mostly Eurasian, organized within a user-friendly interface.

The format of data presentation is binary, i.e., each of the 3800 features has two possible states: "present" or "absent." All features are presented in a hierarchal way, in the form of a tree. Some features can include a paradigm - the field "feature name" contains all possible values, e.g., for the vowel height: "close/mid/open."

\section{2. "LangFam" as a tool for detection of relevant features}

Relevant features of a language family represent a set of features present in most languages of the family under study, but these are very rare in languages from other families (Danilova et al., 2016). Thus, relevant features of a family occur as a set only 
in this family. The detection of relevant features can be very important for typological studies, as it can give information on the possible borrowings and losses of features that were not present in the parent language, or, vice versa, were present only in the proto-language.

A set of relevant features can be defined by contrastive queries using LangFam program. It is a table containing the frequency of occurrence of each feature from the "Languages of the World" database for all families and genera from the database. The frequency of a feature occurrence can have values in the range from 0 , meaning that none of the languages from the family possesses it, to 1 , meaning that the feature is characteristic of all languages from the family under study.

A contrastive query means that a set of relevant features for a language family (or, less often, for a genius) is detected in contrast to another language family. Noteworthy, the absence of genealogic kinship of the two language families must be proven and widely acknowledged. In the present study, we searched for the relevant features of the Uralic languages using contrastive queries to the Altaic languages (Stachowski, 2015), though there are still arguments on the existence of the Altaic family. For example, project ethnologue.com acknowledges the Uralic family, but not the Altaic one. Project wals.info acknowledges both the Uralic and Altaic families. We hold to the hypothesis on the existence of the Altaic macro-family.

The search for relevant features comes down to detecting all features that have the frequency of occurrence over 0.5 (or $50 \%$ of the languages) in the family under study and below 0.05 (or $5 \%$ of the languages) in the contrastive family. The resulting list is the set of relevant features of a language family.

The list of the languages that have a complete set of relevant features can be received from the "Languages of the World" database using the query master integrated into the database. The query master gives an opportunity to obtain a list of languages based on the presence or absence of the following characteristics:

- features,

- attribution to a family or genus

- area of distribution.

It is noteworthy that the number of selected criteria is unlimited, giving the user wide opportunities in work with the data from the database. To get languages with all relevant features, it is necessary to mark the features as "present" in the query master. The result of the search will provide a list of languages possessing all the selected features.

Further work with the set of relevant features includes the application of the so-called variation method, i.e., successive exclusion of one feature from the query. It allows finding languages that have an incomplete set of relevant features (e.g., all but one feature), which can provide information on the evolution of languages.

\subsection{Linguistic geophylogeny}

The present study is based on the method of phylogeography first described in (Hickerson et al., 2010) and later used in works by T.E. Currie et al. (2013), A. Drummond et al. (2012), M. Dunn et al. (2013), P. Lemey et al. (2010), R.S. Walker and L.A. Ribeiro (2011). Given that, we, still, believe that the term "geophylogeny" is more suitable. Thus, it will be used in the present paper.

Recently phylogenies and the methods of phylogenetic analysis are becoming a more a more popular tool for suggesting or proving the hypotheses on the motherland of various language families (Dunn, 2014), (Verkerk, 2017), (Chang et al., 2015). In particular, special attention was gained by Bayesian phylogenetic approaches, which, combined with classical methods of comparative linguistics, can answer long-pending questions (Bouckaert et al., 2012).

XLinguae, Volume 11 Issue 1, January 2018, ISSN 1337-8384, eISSN 2453-711X 
For the present research the phylogenetic tree was taken from ASJP (Wichmann et al., 2016) and manually transformed to minimise the number of intersecting lines from the tree to the map, but still preserving the succession of language separation and the historical deepness of their existence received by the phylogenetic means.

\section{Results}

\subsection{Ancestral homeland detection by linguistic geophylogeny}

The combination of the geographic area of the Uralic languages and the phylogenetic tree is presented in Figure 2 (Here and further (Figures 3, 4, 5) the language numbers in the maps coincide with those from Figure 1.). Some of the languages from the map (Komi-Zyrian, Mator, Moksha, Enets, Nenets) are not presented in the tree, and some of the languages from the tree are not presented in the map (Lule Saami, Skolt Saami, Inari Saami, Estonian Vord, Csango). 



Figure 2: Geographic area of the Uralic languages shown with a phylogenetic tree 
Let us look at the figure more closely. The figure confirms the "Eastern" hypothesis. The group of Samoyedic languages was the first to separate from the Proto-Uralic language. The Nenets people went to the West, and the Selkup settled in the Eastern Ural. Later the Ugrian group (Hungarian, Khanty, Udmurt) separated from the remaining languages. After that, the Hungarians went over the Carpathian Mountains (in 895-896 AD) and occupied the lands in the basin of the Middle Danube River (the territory of modern Hungary) (Molnar, 2001). The Khanty and Udmurt peoples settled in the territory of the Middle and Northern Ural. The remaining part of the Uralic speakers (the Finnish people) settled in the territory of North-Eastern Europe (Southern Saami, Northern Saami, KildinSaami), Karelia (Karelian, Veps), the Baltic in the territory of modern Estonia (Livs, Finnish, Estonian, Votic, Izhor), Northern (Nenets) and Western (Komi, Udmurt) Ural, basins of the Kama and Volga Rivers (Moksha, Erzya, Mari (Hill and Meadow)).

According to the method of linguistic geophylogeny, the geographic area of the ancestral homeland of the Uralic languages was proven to be located in the habitat of Khanty and Mansi. Thus, the present research will be based on one hypothesis "Eastern" (Napolskikh, 1991), as the authors of the paper consider it more substantiated. The method of linguistic geophylogeny showed that the data of the phylogenetic tree built by S. Wichmann et al. (2016) contradict the computation of geographic coordinates of the ancestral homeland of the Uralic languages from (Wichmann et al., 2010). As, in general, phylogenetic trees received by ASJP coincide with the trees built manually within the frames of comparative linguistics, we tend to trust the final tree more than the automatic definition of the language ancestral homeland. Evidently, the method of ancestral homeland computation requires further improvement.

\subsection{Relevant features of the Uralic languages}

The execution of the contrastive query allowed obtaining a set of relevant features of the Uralic languages containing four features. They are given in Table 1. To increase the reliability of the data received by the LangFam program and master of queries of the database "Languages of the World" IL RAS, the researchers double-checked the results, manually. The first feature is the name of the section (e.g., "2.3.4. Case meanings"). The other features are shown to inform to which branch the feature belongs. The numbers of brackets denote the inventory numbers of the features in the database.

Table 1: List of relevant features of the Uralic languages

\begin{tabular}{|c|c|}
\hline 1 & $\begin{array}{lcccr}\text { feature } \quad(535) & \text { 2.2.2.phonological oppositions } & \text { of } & \text { morphological } \\
\text { categories|(537) } & \text {.categorematic/syncategorematic } & \text { words|(540) } & \text {..accent } \\
\text { differences are present } & & & \\
\end{array}$ \\
\hline II & $\begin{array}{l}\text { feature (754) 2.3.4.case meanings|(849) .case of locative relations|(859) } \\
\text {..locative forms of substantive|(878) ...Illative is present }\end{array}$ \\
\hline III & $\begin{array}{l}\text { (754) 2.3.4.case } n \\
\text { ive forms of substanti }\end{array}$ \\
\hline IV & $\begin{array}{l}\text { feature (1765) 2.5.3.simple sentence|(1778) .linear order of } \\
\text { sentence|(1781) ..main } \mid(1782) \text {...SVO is present }\end{array}$ \\
\hline
\end{tabular}

Query master of the database "Languages of the World" IL RAS (Anisimov et al., 2013) allows the user to select some features, according to the presence or absence of which the program must search languages. The first query includes all the features from the previous step (application of the contrastive method). The result of the query presents a list of languages from the database that have a complete set of the relevant features (10 languages in total, all belonging to the Finno-Ugric group): 
- $\quad$ Veps (2)

- $\quad$ Izhor (5)

- $\quad$ Karelian (7)

- Komi-Zyrian (8)

- $\quad$ Komi-Permyak (9)

- $\quad$ Liv (10)

- Moksha (13)

- $\quad$ Finnish (18)

- $\quad$ Erzya (21)

- Estonian (22) (Here and further numbers in brackets are the number of the language in Figures 1-5.).

Figure 3 shows the location of the languages that have a complete set of relevant features. Six of the languages (Estonian, Finnish, Izhor, Karelian, Veps, and Liv) are closely related and belong to the Finnic group. They all are located in the West of the geographic area of Uralic languages.

The next step in the study of the languages and their relevant features is the successive exclusion of one feature from the query. The successive exclusion of features was IIII (There are no reliable data on the accentual difference of categorematic and syncategorematic parts of speech in extinct Kamass and Mator. Thus, it is unreasonable to speak about absence or presence of this feature in these two languages.) did not change the initial set of the languages.

After the exclusion of the fourth feature: "feature (1765) 2.5.3.simple sentence|(1778) .linear order of parts of the sentence|(1781) ..main|(1782) ...SVO is present" the number of languages increases to 14 :

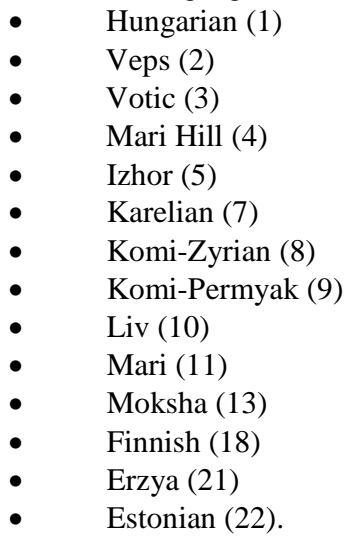




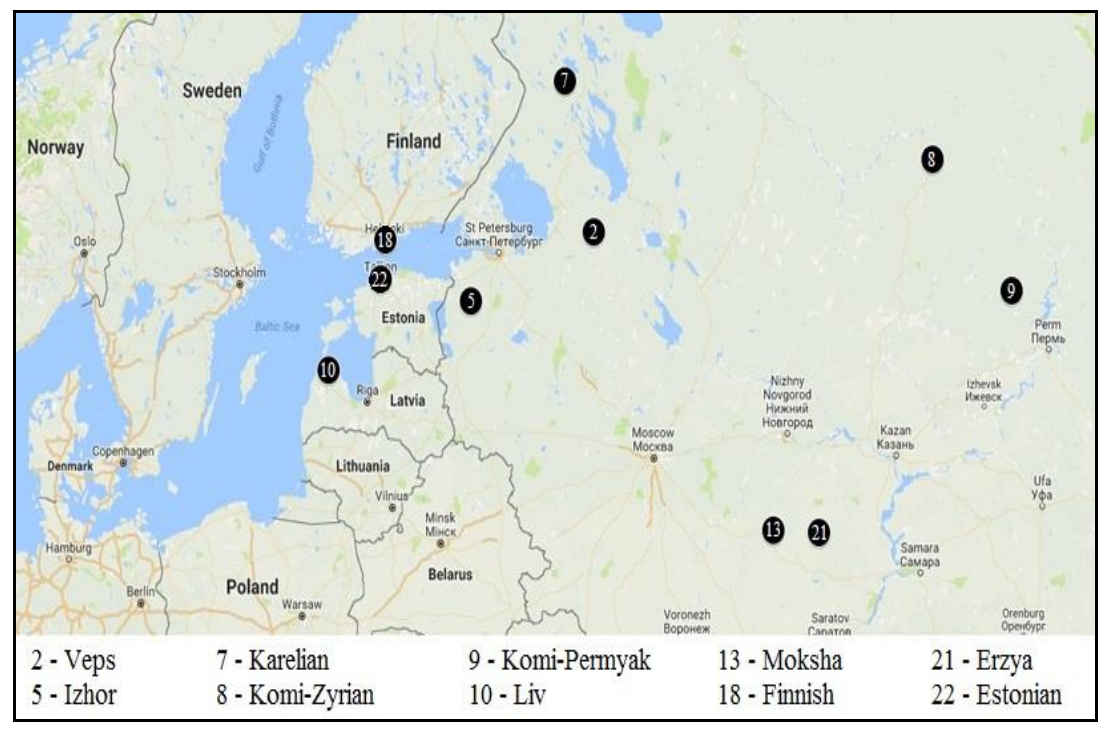

Figure 3: Map of the Uralic languages that have a complete set of relevant features

The result of the query is presented in Figure 4. The map shows the localization of languages that have the complete set of relevant features (circles) and languages with the basic word order different from SVO (drops).

Besides the initial languages, the list also includes Hungarian, Votic, Mari Hill, and Mari. Hungarian has two dominant word orders: SVO and SOV (Kenesei et al., 1998). Votic does not have a prevailing word order (Ariste, 1968). The basic word order in Mari Hill and Mari Meadow is SOV (Pengitov et al., 1961).

The results of queries to the database "Languages of the World" IL RAS aimed at search for languages that have Illative and Inessive cases, languages that have none of them and those having only one Illative case are shown in Figure 5.

Illative and Inessive cases are absent in all Samoyedic languages (drop marker in Figure 5), except Selkup, which has Illative (de Groot, 2017). As for the Finno-Ugric languages, all of them, except Saami and Khanty, have both Illative and Inessive cases. 


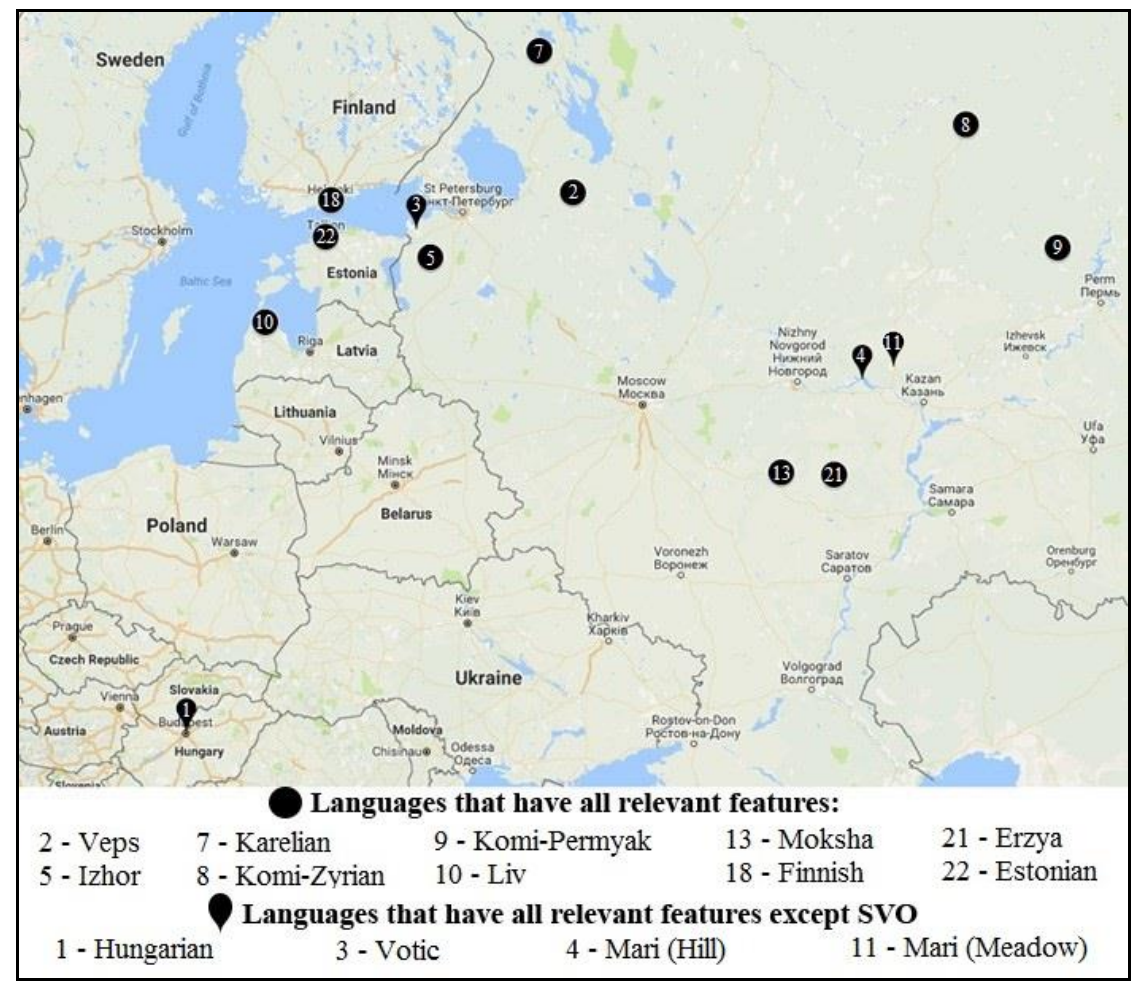

Figure 4: The Uralic languages with a complete set of relevant features (circles) and with all features except the SVO word order (drops) 


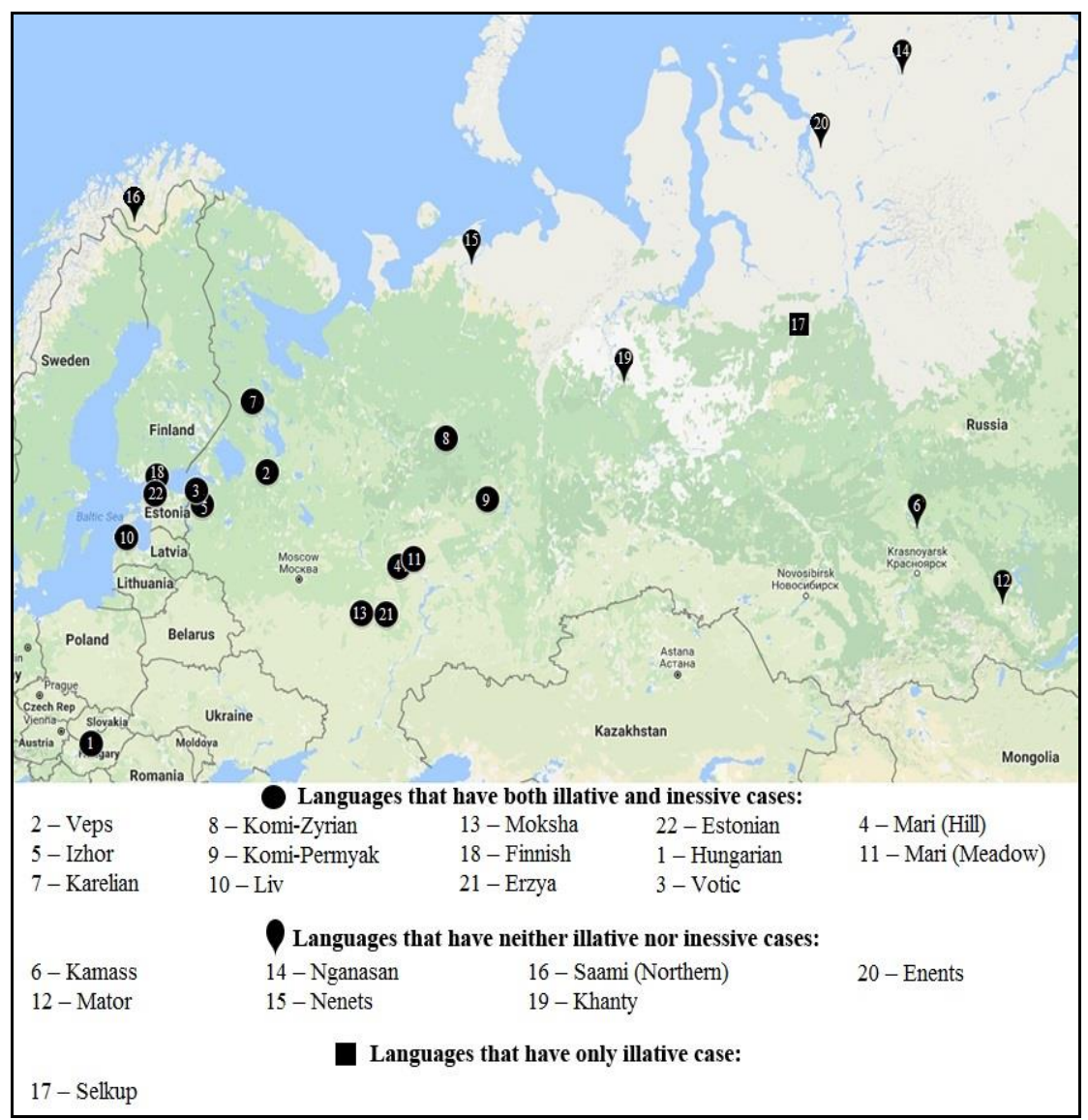

Figure 5: The Uralic languages that have both Illative and Inessive cases (circles), neither of the cases (drops) and only Illative (square)

An interesting question arisen during the analysis of the contrastive query results is an attempt to find an interrelation between the number of cases in the Uralic languages and the basic word order of the sentence. The information about the number of cases and the word order in the Uralic languages is given in Table 2.

Table 2: Number of cases and the word order in the Uralic languages

\begin{tabular}{|l|c|c|}
\hline \multicolumn{1}{|c|}{ Language } & Number of cases & $\begin{array}{c}\text { Basic word order in } \\
\text { sentence }\end{array}$ \\
\hline Hungarian & 23 & SVO \& SOV \\
\hline Veps & 22 & SVO \\
\hline Votic & 14 & free word order \\
\hline Mari Hill & 7 & SOV \\
\hline Izhor & 12 & SVO \\
\hline Kamass (ext.) & 7 & SOV \\
\hline Karelian & 15 & SVO \\
\hline Komi-Zyrian & 16 & SVO \\
\hline Komi-Permyak & 16 & SVO \\
\hline
\end{tabular}




\begin{tabular}{|l|c|c|}
\hline \multicolumn{1}{|c|}{ Language } & Number of cases & $\begin{array}{c}\text { Basic word order in } \\
\text { sentence }\end{array}$ \\
\hline Liv & 12 & SVO \\
\hline Mansi & 6 & SOV \\
\hline Mari & 7 & SOV \\
\hline Mator (ext.) & 7 & SOV \\
\hline Moksha & 13 & SVO \\
\hline Nganasan & 7 & SOV \\
\hline Nenets & 7 & SOV \\
\hline Saami & $8-12$ & free word order \\
\hline Selkup & 13 & SOV \\
\hline Finnish & 15 & SVO \\
\hline Khanty & 10 & SOV \\
\hline Enets & 7 & SOV \\
\hline Erzya & $11+6$ & SVO \\
\hline Estonian & 14 & SVO \\
\hline
\end{tabular}

Figure 6 contains a diagram with all Uralic languages, studied in the present research, except Hungarian, Votic, Saami and Erzya, i.e., all languages with one basic word order (SOV or SVO) and the data on the number of cases of which are the same in different sources. Figure 6 shows that languages with SVO word order have from 12 (Izhor) to 22 (Veps) cases, and languages with SOV word order have from 6 (Mansi) to 13 (Selkup) cases. It means that the transition $\mathrm{SOV} \rightarrow \mathrm{SVO}$ in Uralic was accompanied by the enrichment of the case system.

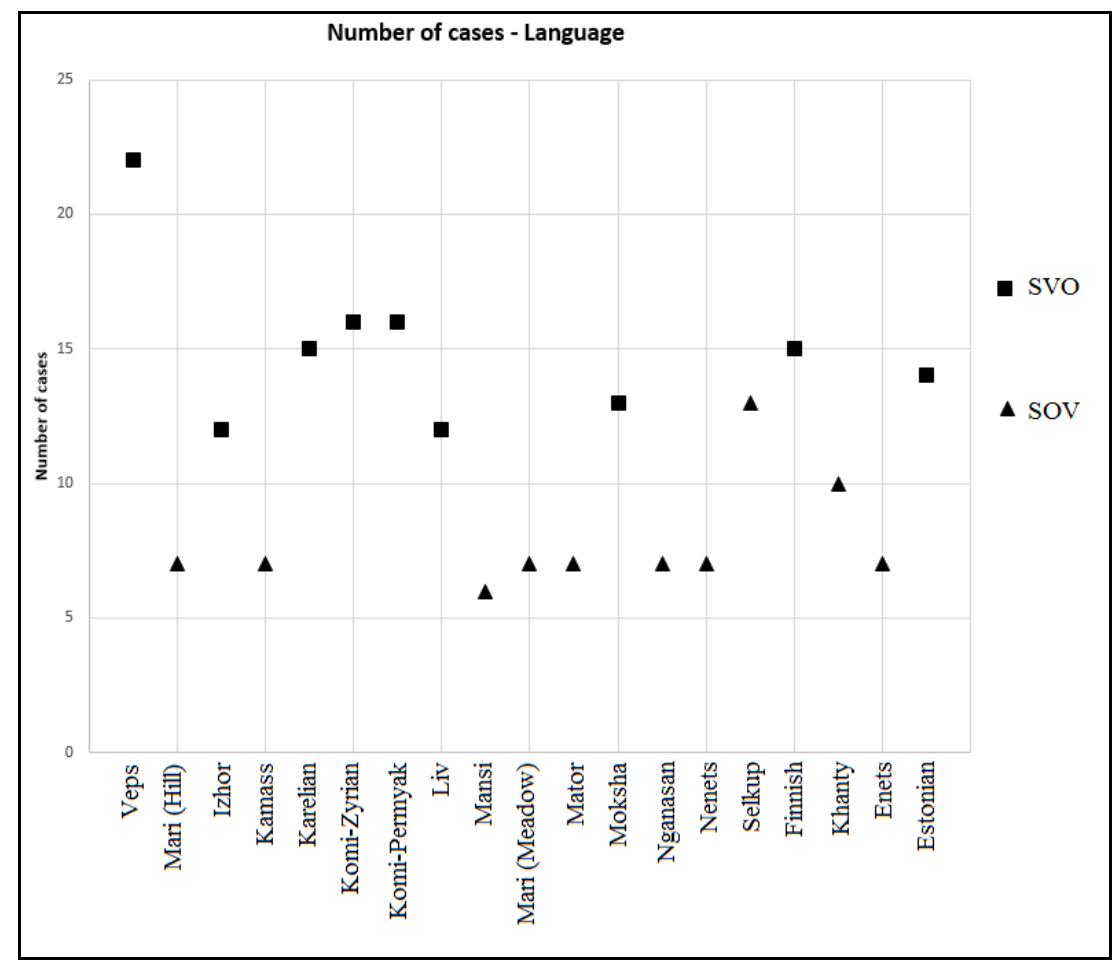

XLinguae, Volume 11 Issue 1, January 2018, ISSN 1337-8384, eISSN 2453-711X 
Figure 6: Scatter diagram of the number of cases in the Uralic languages. Squares indicate languages with SVO, triangles - with SOV.

The coefficient of correlation "Word order (SOV/SVO) - the number of cases" equals 0.83 , which is very high. The geographic localization of languages with SVO word order and a rich case system and languages with SOV word order and a fewer number of cases (Figure 7) show that the first group tends to the West, while the second - to the East. Evidently, it is inappropriate to speak about the universal dependency of one feature on the other.

The map (Figure 7) shows a distinct geographic, and, consequently, genealogic (cf. Figure 2), division of the two groups of languages. Nevertheless, the geographical distribution of the two groups of languages allows us to suggest a hypothesis that the process of the case system enrichment and the process of dominant word order change were taking place simultaneously, under similar conditions. However, if the change of the basic word of the "western" group order can be stipulated by active contacts with the Indo-European languages, the impetus for the enrichment of the cases system remains unclear and requires further study.

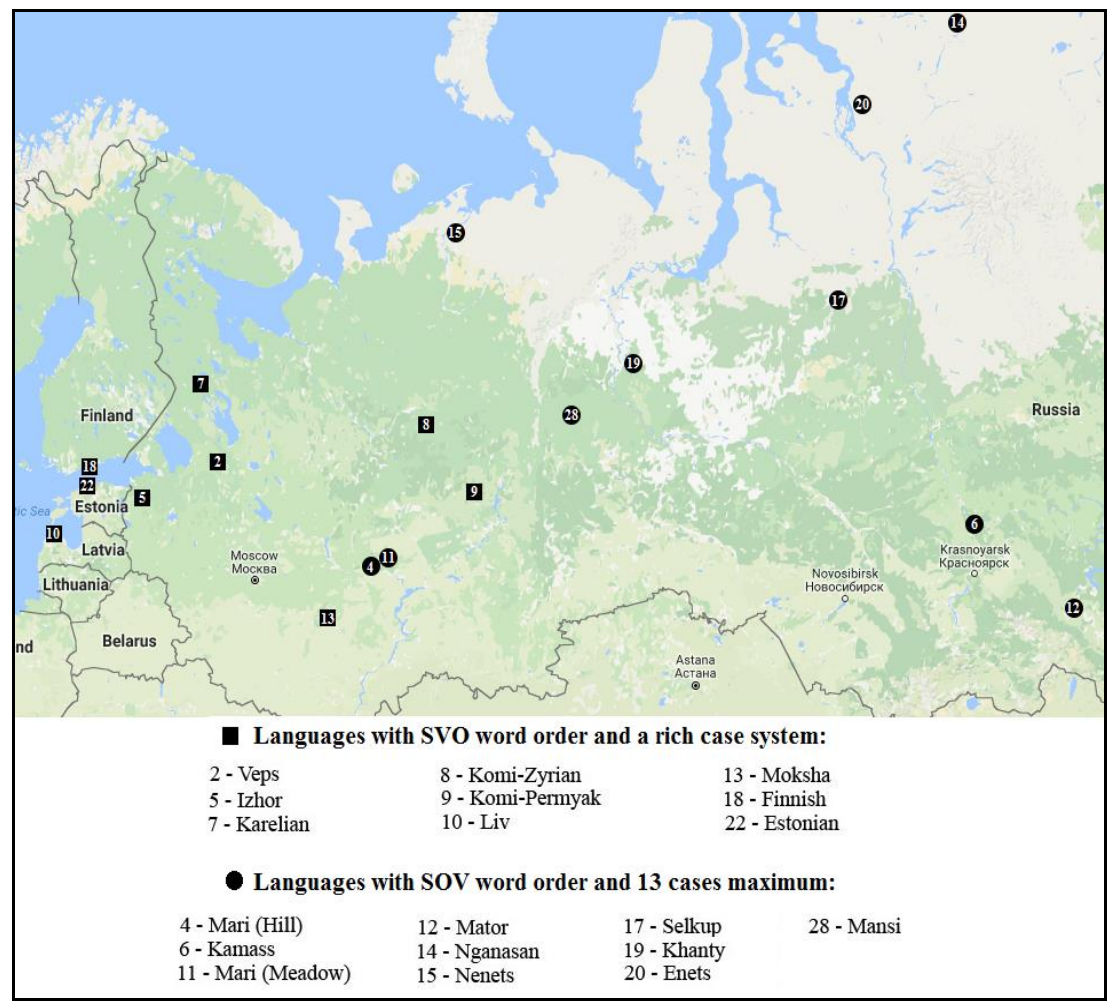

Figure 7: Localization of languages with SVO and over 12 cases and languages with SOV and 13 cases maximum

\subsection{Indo-European languages as a source of word order borrowing}

Taking into consideration P. Hajdu's hypothesis (Hajdu, 1985) on the prevalence of SOV word order in Proto-Uralic, and the data received during the present research, we 
believe that the basic word order in some Uralic languages changed to SVO at a rather late period, as this evolution took place mainly in the western Finno-Ugric languages. We also think that areal contacts of the Uralic languages with each other, as well as with the languages of other families, played an important role in this process (Marcantonio, 2014).

Thus, along with their long history the Uralic languages contacted with the Turkic, Tungusic, Indo-European and, probably, Yeniseian languages. Using LangFam program, we received data on the percent of languages with SOV and SVO word orders for the families mentioned above (the number of languages represented in the database "Languages of the World" IL RAS is given in brackets).

Table 3: Percentage distribution of SOV and SVO word order in various language families

\begin{tabular}{|l|l|l|l|l|}
\hline & \multicolumn{2}{|l|}{ Altaic (76) } & Indo-European(133) & Yeniseian (3) \\
\cline { 2 - 3 } & Turkic (54) & Tungusic (10) & & \\
\hline SOV & $81.48 \%$ & $100.0 \%$ & $39.72 \%$ & $66.0 \%$ \\
\hline SVO & $1.85 \%$ & $0.0 \%$ & $41.13 \%$ & $0.0 \%$ \\
\hline
\end{tabular}

Notes: 1 - There is not enough evidence to define the dominant word order for Kott.

As shown in Table 3, only the Indo-European languages have a significant part of languages with the basic SVO word order. However, at the oldest period of their existence, they were also characterized by the sequence subject-object-verb (Lehmann, 1974).

Now let us proceed to the basic word order in different groups of the Indo-European language family (Table 4).

Noteworthy, the dominance of SVO word order is characteristic of the modern western Indo-European languages, and it is very rare for the Indo-Aryan branch. Thus, the Uralic languages could acquire the order subject-verb-object as a result of contacts with the Indo-European languages of the western area.

Table 4: Percentage distribution of word order SOV and SVO in various branches of the Indo-European languages (The decomposition of the Indo-European family into branches is given according to the genealogic index of the "Languages of the World" IL RAS database.)

\begin{tabular}{|l|l|l|l|l|l|}
\hline Word Order & $\begin{array}{l}\text { Germanic } \\
(14)^{1}\end{array}$ & Indo-Aryan (9) & Iranian (38) & $\begin{array}{l}\text { Romance } \\
(25)\end{array}$ & $\begin{array}{l}\text { Slavic } \\
(14)\end{array}$ \\
\hline SOV & $0.0 \%$ & $100 \%$ & $64.29 \%$ & $0.0 \%$ & $7.14 \%$ \\
\hline SVO & $92.86 \%$ & $0.0 \%$ & $4.76 \%$ & $92.0 \%$ & $92.86 \%$ \\
\hline
\end{tabular}

Notes: 1 - The dominant word order for Gothic is not reliably defined.

As shown in (Antonsen, 1975; Hopper, 1975; Lehmann, 2005-2007), the verb in the preliterate Germanic languages was placed at the end, which is a relic of the ProtoIndo-European syntax. It brings to the conclusion that the modern system of the word order is a result of the evolution of the last centuries.

Thus, the SVO word order in the Uralic languages of the western and northern area

XLinguae, Volume 11 Issue 1, January 2018, ISSN 1337-8384, eISSN 2453-711X 
can be the result of contacts, first of all, with the Germanic and Slavic branches. Probably, contacts between the different Uralic languages also played an important role in this process. However, the genetic closeness of most languages that underwent the evolution in the word order (the Finnic languages) does not seem to be the key factor. The word order in other Uralic languages remained subject-object-verb, in some respect due to the "conserving" influence of the neighbor languages.

The SOV word order in Proto-Indo-European and Proto-Germanic can explain why the process of transition from one basic word order to another did not begin earlier, despite the long contacts between the Indo-European and Uralic languages, and it can also help define the lower borderline of the beginning of the process to be not earlier than the early second millennium AD.

\section{Discussion}

As shown in previous studies (Danilova et al., 2016; Makarova\&Polyakov, 2015), relevant features of a language family are not always genealogical. In particular, Proto-Uralic did not have Inessive and Illative cases. Evidently, these two cases developed in Proto-Finno-Ugric after the disintegration of the proto-language into two branches: Proto-Finno-Ugric and Proto-Samoyedic, as the latter do not have the cases in question. Besides, the basic SVO word order also was not characteristic of ProtoUralic. It was borrowed from the Indo-European languages as a result of tight areal contacts. Though the SVO word order is not a relevant feature of the Indo-European languages $(41.13 \%$ of all Indo-European languages have it), it is the most widespread. Noteworthy, the SVO word order is not genealogic for the Indo-European languages as well, as both Proto-Indo-European and Proto-Uralic had SOV (Mallory \& Adams, 1997).

Noteworthy, the process of basic word order change was accompanied by the enrichment of the cases system of the latter. Presumably, new cases (compared to the proto-language) developed as a result of grammaticalization of postpositional construction, which are very frequent in the Uralic languages. Nevertheless, the question what provided an impetus for this process has not found an answer in studies of modern Uralic.

Based on (Greenberg, 1963) and succeeding works (Comrie, 1989; Hoffman, 1996) dedicated to the topic, it can be noted that one of the means of expressing locative relations in the Finnic languages and Saami are constructions with prepositions, which do not occur in other Uralic languages.

Speaking about the areal contacts, we can say that this question remains unanswered. So far it is only possible to speak about some "point" phenomena. An example of such phenomena is broadened semantics of the second Prolative in the southern dialect of Veps under the influence of Russian, or the change of morphosyntactic characteristics of Liv translative-comitative under Lithuanian influence (Grünthal, 2003).

Another interesting fact is that Selkup is the only Samoyedic language that has the Illative case. This case is absent in languages of peoples, whose area partially intersects with Selkup - the Khanty, Evenki, and Ket. Probably, it was borrowed from Komi-Zyrian after the XVI c., when a mass migration of people from the European part of Russia to Siberia began (Kuznetsova et al., 2002). However, this question remains open and requires further investigation.

A high level of correlation between a certain word order (SOV/SVO) and a number of cases was found. Though it is wrong to suggest a universal interdependency of the two grammar features, it is noteworthy that those Uralic languages that underwent the transition from SOV word order also have an enriched case system compared to the proto-language (from 12 to 22 cases opposed to 8 cases in Proto-Uralic). It can be explained by the fact that the change of the basic word order and the enrichment of the case system were occurring under similar circumstances. Nevertheless, while $\mathrm{SOV} \rightarrow \mathrm{SVO}$ change is acknowledged to have happened under the influence of the 
Indo-European languages, the impetus for the development of the big number of additional cases compared to the proto-languages, which is likely to be the result of grammaticalization of postpositional constructions, requires further study.

The authors applied the method of linguistic geophylogeny when a phylogenetic tree is combined with a map of the distribution of languages. Thus, the geographic localization of the ancestral homeland becomes more obvious. This method can be applied for localization of the ancestral homeland of other language families.

The method of contrastive queries, which had already been tested by us, was used for the Uralic languages. It helped once again demonstrate its possibilities in the sphere of typological and areal researches. The method of contrastive queries and the localization of the ancestral homeland give a gradient (vector of change) of grammar features in a family in the dynamics of its development.

\section{Conclusion}

The Uralic languages have not been studied enough, which can be testified by the existence of different hypotheses on the localization of their ancestral homeland. The present research used new methods and new linguistic resources to specify these data. Particularly, using the method of linguistic geophylogeny, the authors confirmed the "Eastern" hypothesis of the origin of the Uralic languages. Besides, contrastive queries to the "Languages of the World" IL RAS database helped define the relevant features of the Uralic languages. Once again it was proven that the SVO word order is relevant, but not genealogic for Uralic. Based on the word order studies in Estonian and Finnish till the $19^{\text {th }}$ century, the authors claim that the change of the dominating word order began as late as in the $16^{\text {th }}$ century.

Correlation between a certain word order (SOV/SVO) and the number of cases was found. The paper presented a map showing the change of the case system and the basic word order of a simple clause as a result of areal contacts.

The absence of some Uralic languages in the "Languages of the World" database can be mentioned as a limitation of the present work. Though their inclusion would not influence the results of the contrastive query to any considerable extent, this fact still made it impossible to analyze all representatives of the family regarding their relevant features.

The possible direction of future work includes a more thorough study on the time when the basic word order changed from SOV to SVO in some Uralic languages. Another question that needs attention is the reason for the significant enrichment of the case system of the "Western" Uralic languages, as none of the language families that were in close contacts with the Uralic languages is characterized by such a high number of cases.

\section{Acknowledgement}

The research was supported by RFBR grant \# 16-06-00187.

We would like to thank Dr. Elena B. Markus for valuable comments and advice.

\section{Authors' contribution}

V. Polyakov formulated the research question of the present paper, realized the LangFam program and wrote sections Discussion, Conclusion. The method of contrastive queries and the idea of correlation "word order - the number of cases" belong to V. Polyakov.

E. Paramoshko found the initial set of relevant features, made a review of hypotheses on the motherland and areal contacts of Uralic languages and collected initial data on the distribution of SOV and SVO word order in language families.

XLinguae, Volume 11 Issue 1, January 2018, ISSN 1337-8384, eISSN 2453-711X 
E. Makarova provided the visualization of the data on maps, conducted a manual verification of queries to the database "Languages of the World," provided a bibliography and translated the article.

The work on the database "Languages of the World" is conducted by E. Makarova and V. Polyakov.

\section{Bibliographic references}

ABAEV, V. 1972. On the ancestral homeland and ancient migrations of the IndoAryan peoples. Moscow. Ancient East and classical antiquity. pp. 26-37.

ADLER, E. 1966. Votic language. Moscow. Languages of the peoples of the USSR: the Finno-Ugric and Samoyedic languages. Eds. V. Lytkin, K. Maitinskaya, P. Ariste, M. Kolyadenkov, B. Serebrennikov, N. Tereshchenko. vol. III, pp. 118-137.

ANISIMOV, I. - POLYAKOV, V. - SOLOVYEV, V. 2013. Database "Languages of the World." New Version. New Research Horizons. Rostov-on-Don. Proceedings of the First International Forum on Cognitive Modeling. Part I. Eds. S. Masalova, V. Solovyev. pp. 27-34. ISBN 918-5-87872-731-0.

ANTONSEN, E. 1975. A concise grammar of the Older Runic Inscriptions. Tubingen: Max Niemeyer Verlag. ISBN 3-484 60052-7.

ARISTE, P. 1968. A grammar of the Votic language. Bloomington: Indiana University. ISBN 978-0-87750-024-7.

BOUCKAERT, R. et al. 2012. Mapping the origins and expansion of the IndoEuropean language family: 6097 // Science. American Association for the Advancement of Science. Vol. 337, № 6097. P. 957--9603 p. DOI: 10.1126/science. 1219669

BRATTICO, P. J. 2016. Is Finnish topic prominent? In: Acta LinguisticaHungarica, Vol. 63, No. 3, September 2016. DOI: 10.1556/064.2016.63.3.2

BUBRIH, D. 1949. Grammar of literary Komi. Leningrad: Zhdanov Leningrad State University Press.

CASTRÉN, M. 1849. Nordic travel and research. St.-Petersburg: Book printing office of the Imperial Academy of Sciences. ISBN 978-5-8804-6609-2.

CHANG, W. - CATHCART, C. - HALL, D. - GARRETT, A. 2015. Ancestryconstrained phylogenetic analysis supports the Indo-European steppe hypothesis. Language 91: 194-244.

COLLINDER, B. 1965. An introduction to the Uralic Languages. Berkeley and Los Angeles: University of California Press.

COMRIE, B. 1989. Language Universals and Linguistic Typology: Syntax and Morphology. Chicago: University of Chicago Press. ISBN 0-226-11433-3.

CURRIE, T.E. - MEADE, A. - GUILLON, M. - MACE, R. 2013. Cultural phylogeography of the Bantu languages of Sub-Saharan Africa. In: Proceedings of the Royal Society B: Biological Sciences, vol. 280, n. 1762, pp. 1-8. ISSN 0962-8452.

DANILOVA, V. - MAKAROVA, E. - POLYAKOV, V. - SOLOVYEV, V. 2016. Frequency-based relevant grammar features of the Caucasian languages. In: Indian Journal of Science and Technology, vol. 9, n. 11, pp. 1-10. ISSN Print: 0974-6846. ISSN Online: 0974-5645.

Database "Languages of the World" of IL RAS. 2013. Available online: https://cloud.mail.ru/public/KEhw/paQ35qYAi

DRUMMOND, A. - SUCHARD, M. - XIE, D. - RAMBAUT, A. 2012. Bayesian phylogenetics with BEAUTY and the BEAST 1.7. In: Molecular Biology and Evolution, vol. 29, pp. 1969-1973.ISSN: 0737-4038. ISSN Online: 1537-1719.

DRYER, M.S. 1992. The Greenbergian Word Order Correlations. In: Language, vol. 68, pp. 81-138. ISSN:0097-8507. ISSN Online:1535-0665.

DUNN, M. 2014. Language phylogenies. In Claire Bowern and Bethwyn Evans (eds.), Routledge Handbook of Historical Linguistics, 190-211. London: Routledge. 
DUNN, M. - KRUSPE, N. - BURENHULT, N. 2013. Time and place in the prehistory of the Aslian languages. In: Human Biology, vol. 85, n.1, pp. 383-399. ISSN: 0018-7143. ISSN Online: 1534-6617.

EHALA, M. 2006. The Word order of Estonian: implications to universal language. In: Journal of Universal Language, vol. 7, pp. 49-89. ISSN 1598-6381.

EVSEVIEV, M. 1931. Principles of Mordvinian grammar = Erzya grammar. Moscow: Centrizdat.

GELL-MANN, M. - RUHLEN, M. 2011. The origin and evolution of word order. In: Proceedings of the National Academy of Sciences of the United States of America, vol. 108, n.42, pp. 17290-17295. ISSN:0027-8424. ISSN Online:1091-6490.

GREENBERG, J.H. 1963. Universals of language. Cambridge: MIT Press, pp. 73113. ISBN 026257008 4. ISBN 0262070200.

GRUNTHAL, R. 2003. Finnicadpositions and cases in change. Helsinki: Sociétéfinno-ougrienne. ISBN 978-952-5667-25-7.

HAJDU, P. 1985. Uralic languages and people. Moscow: Progress.

HAKULINEN, L. 1961. The structure and development of the Finnish language. Bloomington: Indiana University Press. ISBN 978-0700708031.

HARMATTA, J. 1977. Iranian and Finno-Ugric, Iranian and Hungarian. Budapest. Hungarian historical studies. pp. 167-182. ISSN 0418-4556.

HARMS, R.T. 1962. Estonian grammar. Bloomington: Indiana University Press. ISBN 978-0700708123.

HAUGAN, J. 2001. Old Norse word order and information structure. PhD thesis. Trondheim. ISBN 82-471-5060-3.

HAKKINEN, J. 2012. Early contacts between Uralic and Yukaghir. Helsinki. Per UralesadOrientemIterpolyphonicummultilingueFestskrifttillägnadJuhaJanhunenpåhan ssextioårsdag den 12 februari 2012. Suomalais-UgrilaisenSeuranToimituksia. Eds. T. Hyytiäinen, L. Jalava, J. Saarikivi, E. Sandman. vol. 264, pp. 91-101. ISBN 978-9525667-33-2. ISSN 0355-0230.

HICKERSON, M. - CARSTENS, B. - CAVENDER-BARES, J. - CRANDALL, K. - GRAHAM, C. - JOHNSON, J. - RISSLER, L. - PEDRO, F. - YODER, A. 2010. Phylogeography's past, present, and future: 10 years after. In: Molecular Phylogenetics and Evolution, vol. 54, n. 1, pp. 291-301. ISSN: 1055-7903. ISSN Online: 1095-9513.

HOFFMAN, J. 1996. Syntactic and paratactic word order effects. PhD thesis. College Park.

HONTI, L. 2013. Comments on Uralic historical phonology. ActaLinguisticaHungarica. Vol. 60, No. 1, pp. 1-68. DOI: 10.1556/ALing.60.2013.1.1 HOPPER, P. 1975. Syntax of the simple sentence in Proto-Germanic. TheHague: Mouton.

JANHUNEN, J. 2009.Proto-Uralic - what, where and when? In: SuomalaisUgrilaisenSeurantoimituksia, vol. 258, pp. 57-78. ISBN 978-952-5667-11-0. ISSN 0355-0230. Available online: http://www.sgr.fi/sust/sust258/sust258_janhunen.pdf

KALIMA, J. 1936. Baltic Loanwords in the Finnic Languages. Helsinki: SuomalaisenKirjallisuudenSeura.

KENESEI, I. - VAGO, R.M. - FENYVESI, A. 1998. Hungarian (Descriptive grammars). London / New York: Routledge. ISBN 9780415021395. ISBN 9780203192238.

KLEMM, A. 1928-1942. Hungarian historical syntax. Vol. I - 1928, vol. II - 1940, vol. III - 1942. Budapest: Magyar tudományos.

KUZ'MINA, E. 2007. The origin of the Indo-Iranians. Leiden, Boston: Brill. ISSN 1574-3586. ISBN 9789004160545.

XLinguae, Volume 11 Issue 1, January 2018, ISSN 1337-8384, eISSN 2453-711X 
KUZNETSOVA, A. - KAZAKEVICH, O. - GRUSHKINA, E. - KHELIMSKY, E. 2002. Selkup language. Saint-Petersburg: branch office of "Prosveshchenie". ISBN 509-005259-X.

LEHMANN, W.P. 1974. Proto-Indo-European Syntax. Austin: University of Texas Press.ISBN 0-292-76419-7.

LEHMANN, W.P. 2005-2007. Chapter 5. Syntax. In: A Grammar of Proto-Germanic. Ed. J. Slocum. Available online: http://folksprak.org/common/material/pdf/AGrammar-of-Proto-Germanic.pdf

LEMEY, P. - RAMBAUT, A. - WELCH, J.J. - SUCHARD, M.A. 2010. Phylogeography takes a relaxed random walk in continuous space and time. In: Molecular Biology and Evolution, vol. 27, n. 8, pp. 1877-1885. ISSN: 0737-4038. ISSN Online: 1537-1719.

MAJID, A. - JORDAN, F. - DUNN, M. 2015. Semantic systems in closely related languages. Language Sciences. Volume 49, May 2015, Pages 1-18. DOI: 10.1126/science. 1219669

MAKAROVA, E. - POLYAKOV, V. 2015. The origin of the article in the IndoEuropean languages of Western Europe. In: Mediterranean Journal of Social Sciences, vol. 6, n. 5S4, pp. 61-75. ISSN 2039-9340.

MALLORY, J.P. - ADAMS, D.Q. (Eds.). 1997. Encyclopedia of Indo-European culture. London: Fitzroy Dearborn Publishers. ISBN 1-884964-98-2.

MARCANTONIO, A. 2002.The Uralic Language Family: Facts, Myths, and Statistics. Oxford: Willey-Blackwell. ISBN: 978-0-631-23170-7.

MARCANTONIO, A. 2014. Uralic vs Indo-European contacts: borrowing vs local emergence vs chance resemblances. Eestijasoome-ugrikeeleteaduseajakiri. Journal of Estonian and Finno-Ugric Linguistics, [S.1.], v. 5, n. 2, p. 29-50, dec. 2014. ISSN 2228-1339.

MOKSHIN, N. 2009. Origin of Finno-Ugric (Uralic) peoples. In: Finno-Ugric world, vol. 3, pp. 42-53. ISSN 2076-2577.

MOLNAR, M. 2001.A concise history of Hungary. Cambridge:Cambridge University Press.ISBN978-0-521-66736-4.

NAPOLSKIKH, V. 1991. Oldest stages of the origin of peoples of the Uralic language family: data of mythological reconstruction. PhD thesis. Moscow. ISSN 0868-586X.

NAPOLSKIKH, V. 1997. Introduction to historical Uralic studies. Izhevsk: Udmurt University of History, Languages and Literature of Uralic Department of RAS. ISBN 5-7691-0671-9.

PENGiTOV, N. - GALKIN, I. - ISANBAEV, N. (Eds.). 1961. Modern Mari. Morphology. Yoshkar-Ola: Mari Book Publisher.

PEREVOSHCHIKOV, P. - VAKHRUSHCHEV, V. - ALATYREV, V. POZDEEVA, A. - TARAKANOV, I. (Eds.). 1962. Grammar of modern Udmurt. Phonetics and morphology. Izhevsk: Udmurt Book Publisher.

PONARYADOV, V. 2001. Word order in Permic languages in comparative and typological aspect: simple clause. PhD thesis. Syktyvkar.

REMMEL, N. 1963. Word order in Estonian sentence. Tallinn. Estonian problems of language syntax. Ed. T.R. Kress. pp. 216-389.

RIESE, T. 2001. Vogul (Mansi). München: Lincom Europa.

RIJKHOFF, J. 2004. The noun phrase. Oxford: Oxford University Press. ISBN 0-19926964-5.

SEREBRENNIKOV, B. 1967. Historical morphology of the Mordvinic languages. Moscow: Nauka.

SILNITSKY, G. 2006. Semantics. Grammar. Quantitative and typological linguistics. Smolensk: Smolensk Centre of Scientific and Technical Information. ISBN 5-93738032-0. 
SONG, J.J. 2012.Word order. Cambridge: Cambridge University Press. ISBN 978-0521-87214-0, 978-0-521-69312-7.

STACHOWSKI, M. 2015. Turkic Pronouns against a Uralic Background. Iran and the Caucasus, Volume 19, Issue 1, pages 79 - 86. 2015. DOI: 10.1163/1573384X20150106. ISSN: 1609-8498 E-ISSN: 1573-384X

TOMLIN, R. 1986. Basic word order: functional principles. London: Croom Helm. ISBN: 0-7099-2499-2.

TSYPANOV, E. 2008. Comparative review of the Finno-Ugric languages. Syktyvkar: Kola. ISBN: 978-5-88186-835-2.

Uralic Essive and the Expression of Impermanent State. 2017. Ed. by Casper de

Groot. John Benjamins, November 2017. xix, 555 pp.

VERKERK, A. Phylogenies: Future, not fallacy. Language Dynamics and Change 7(1):127-140, May 2017. DOI: 10.1163/22105832-00601013.

WALKER, R.S. - RIBEIRO, L.A. 2011. Bayesian phylogeography of the Arawak expansion in Lowland South America. In: Proceedings of the Royal Society B: Biological Sciences, vol. 278, n. 1718, pp. 2562-2567. ISSN: 0962-8452.

WICHMANN, S. - HOLMAN, E.W. - BROWN, C.H. (Eds.). 2016. The ASJP Database (version17). Available online: http://asjp.clld.org/

WICHMANN, S. - MULLER, A. - VELUPILLAI, V. 2010. Homelands of the world's language families: a quantitative approach. In: Diachronica, vol. 27, pp. $247-$ 276. ISSN:0176-4225. ISSN Online:1569-9714.

WIEDEMANN, F.J. 1838. On the former areas of the Chadian peoples and their linguistic contacts with the peoples of Central China. Leningrad.ISBN 978-9949-22696-2.

WINKLER, E. 2001. Udmurt. Languages of the World. Materials 212. München: Lincom Europa. ISBN 389586272 X.

ZAITSEVA, M. 1981. Grammar of Veps (Phonetics and morphology). Leningrad: Leningrad department of "Nauka".

Words: 8544

Characters: 55674 (30,93 standard pages)

Assoc. Prof. Vladimir N. Polyakov, PhD

National University of Science and Technology "MISiS"

4 Leninsky Ave. , 119049, Moscow

Russia

vladimir.polyak2017@yandex.ru

Elena A. Makarova

Institute of Linguistics

Russian Academy of Sciences

1 Bolshoy Kislovsky lane, building 1

125009, Moscow

Russia

makarovaelena57@rambler.ru

Ekaterina S. Paramoshko

Department of Theoretical and Applied Linguistics

Philological Faculty

Lomonosov Moscow State University

1 Leninskie Gory, 119899, Moscow

Russia

paramoshko52@mail.ru

XLinguae, Volume 11 Issue 1, January 2018, ISSN 1337-8384, eISSN 2453-711X 